\title{
АДМИНИСТРАТИВНО-ПРАВОВЫЕ МЕРЫ ОБЕСПЕЧЕНИЯ БЕЗОПАСНОСТИ СОЦИАЛЬНОЙ СФЕРЫ ОТ КОРРУПЦИИ
}

\begin{abstract}
Аннотация. Предметом статьи являются проблемы административно-правового и характера, связанные с противодействием коррупции в социальной сфере. Автором подробно проводится теоретико-правовой анализ административно-правового регулирования противодействия коррупции в социальной сфере с позиции конституционного права. Рассматриваются авторские позиции относительно понятия противодействия коррупции. Основное внимание в статье уделяется разработки методов и методологии конституционно-правового регулирования противодействия коррупции в социальной срере. Кроме того, в статье проводится теоретико-правовой анализ понятий концепций развития административного права в контексте противодействия коррупции в нашей стране. Методологическую основу статьи составили современные достижения теории познания. В проиессе исследования применялись общефилософский, теоретический, общерилософские методы (диалектика, системный метод, анализ, синтез, аналогия, дедукция, наблюдение, моделирование), традиционно правовые методы (формально-логический), а также методы, используемые в конкретно-социологических исследованиях (статистические, экспертные оценки и др.). Основной вывод, который сделан по итогам исследования, состоит в том, что в настоящее время для обеспечения правопорядка в социальной срере необходимо совершенствовать формы и методы административно-правового регулирования противодействия коррупции. Основным вкладом, который сделан автором в настоящей статье это необходимость развития конституционно-правового регулирования противодействия коррупции. Новизна статьи заключается в разработке предложений по развитию форм и методов административно-правового регулирования социальной сферы.
\end{abstract}

Ключевые слова: администрирование, социальная, коррупция, служба, минимизация, риск, противодействие, безопасность, стандарт, сфера.

Abstract. The research subject is the range of administrative problems of corruption prevention in the social sphere. The author analyzes administrative rules of corruption prevention in the social sphere from the position of constitutional law. The paper demonstrates the author's positions on the corruption prevention concept. The main attention is paid to the development of methods and methodology of constitutional regulation of corruption prevention in the social sphere. Besides, the author analyzes the concepts of administrative law development in the context of corruption prevention. The research methodology is based on the recent achievements in epistemology. The author applies general philosophical and theoretical methods (dialectics, the system method, analysis, synthesis, analogy, deduction, observation and modeling), traditional legal methods (formal logical), and the methods of specific sociological research (statistical, expert evaluations, etc.). The author concludes that at present, in order to ensure legality in the social sphere, it is necessary to improve forms and methods of administrative regulation of corruption prevention. The author states the necessity to develop constitutional regulation of corruption prevention. The scientific novelty consists in the proposals about the development of forms and methods of administrative regulation of the social sphere.

Key words: sphere, standard, safety, prevention, risk, minimization, service, corruption, social, management.

K оррупция, как известно, возникает чаще всего там, где есть управление, управленческие отношения, властные полномочия, субординация. В социальной сфере управленческие отношения также имеют место быть, и они весьма уязвимы для коррупции. Но кроме должностных лиц органов социальной защиты, здравоохранения, образования и иных органов исполнительной власти, коррупционерами зачастую являются, не подпадающие под приложение 1 к ст.285 УК РФ субъекты: врачи, медсестры, учителя, преподаватели и иные лица, не обладающие властными полномочиями и не исполняющие организационно-распорядительные и административно-хозяйственные функции, но осуществляющие свою общественно-полезную профессиональную деятельность, которая пользуется у общества особым спросом. Уголовно-правовыми средствами и способами наказать таких коррупционеров достаточно сложно, и, к сожалению, об этом известно не только правоохранительным органам, но и самим профессионалам, вступившим на коррупционный путь. Поэтому среди правовых мер противодействия коррупции в данном случае велика роль именно административно-правовых средств, в частности, мер дисциплинарного воздействия на коррупционеров, имеющих административно-правовую природу возникновения и развития. Необходимость детального исследова- 
ния административно-правовых мер обеспечения безопасности социальной сферы от коррупции объясняется ещё и тем, что в науке они не получили должного юридического осмысления. Если уголовно-правовым средствам противодействия коррупции посвящено огромное количество научных диссертационных и монографических трудов таких учёных-криминологов как С.В. Плохов, Н.А. Егорова, Х.А. Ибрагимова, И.А. Мамедов, А.И. Мизерий, Д.В. Мирошниченко, Л.В. Петелина, У.Т. Сайгитов, И.М. Сичинава, Т.А. Хабибуллин, А.В. Шнитенков, Е.В. Яковенко и ряд других, то административноправовым средствам противодействия коррупции подобного рода трудов посвящено значительно меньше. А между тем причины коррупционной преступности заложены, на наш взгляд, именно в административно-правовом характере коррупции. Уголовно-правовые и криминологические меры противодействия коррупционным преступлениям в социальной сфере будут неэффективны, если административно-правовые средства борьбы с коррупцией не используются, либо используются недостаточно.

Наиболее полно и детально исследовал административно-правовые средства предупреждения и пресечения коррупции в своей докторской диссертации знаменитый ученый в области административного права А.В. Куракин. Кроме него, данную тему на монографическом уровне исследовали А.А. Шевелевич, Д.А. Повный, Н.В. Хлонова. Административно-правовая сущность коррупции, по нашему глубокому убеждению, важна и необходима для более полного исследования уголовно-правовых и криминологических мер противодействия ей, что является темой нашего диссертационного исследования. Кроме того, началом коррупционных преступлений зачастую служат административные коррупционные правонарушения и аморальные коррупциогенные проступки, возникающие в сферах публичного и частного управления. Не исключением является и социальная сфера, особенно наиболее коррупционные её отрасли - образование и медицинское обслуживание населения, в которых, как показывает практика и социологические опросы, большую часть коррупционеров составляют не должностные лица соответствующих учреждений и организаций, а профессиональные сотрудники, непосредственно оказывающие образовательные и медицинские услуги, не подпадающие под категорию должностных лиц указанных в приложении 1 к ст.285 УК РФ, а значит не могущих быть субъектами коррупционных преступлений. Но они также как и должностные лица, по нашему глубокому убеждению, должны привлекаться к уголовной ответственности за коррупционные преступления и на протяжении всего нашего исследования мы постараемся это доказать и предложить внести изменения в действующее уголовное законодательство. В данном же параграфе для более глубокого уяснения причин и условий, способствующих совершению коррупционных преступлений, мы будем исследовать и анализировать управленческие, административно-правовые средства противодействия коррупции в социальной сфере, доказывая их значимость и роль в предупреждении и пресечении коррупционной преступности, минимизации ее негативных последствий.

Как справедливо отмечает А.В. Куракин, «для эффективного административно-правового предупреждения и пресечения коррупции в системе государственной службы РФ необходимо формирование общественного мнения, нетерпимости к коррупции, а также искоренение правового нигилизма. В настоящее время необходимого общественного мнения для предупреждения и пресечения коррупции пока нет» [1].

В подтверждение своих слов, он приводит данные исследования Института социологии Российской академии наук. Так, отношение россиян к тому, что для решения своих проблем гражданам приходится нередко давать взятки, выглядит следующим образом. С этим нужно бороться, поскольку коррупция разлагает нас и нашу власть - считает 56,4 \% опрошенных респондентов; коррупция это необходимая часть нашей жизни, без этого ничего нельзя сделать - 11,1 \%; коррупции можно избежать, но со взятками легче достичь нужного результата - 28,5 \%; 4 \% опрошенных затруднилось ответить. Оценки россиян относительно распространения коррупции в высших органах власти выглядят следующим образом. Отдельные должностные лица в высших органах власти используют свое положение для личного обогащения - 29,8 \%. То, что большинство должностных лиц в высших органах власти работает честно, только за зарплату, - считает 3,4 \%. Подавляющее большинство должностных лиц в высших органах власти используют свое положение в личных, корыстных целях - считает 60,1 \%. 6,6 \% опрошенных граждан затруднилось ответить на поставленный вопрос [2].

Вышесказанное говорит о том, что одними уголовно-правовыми средствами победить коррупцию нельзя, путем должного использования административно-правовых средств можно противостоять коррупции в сфере государственного управления, но самым главным и эффективным средством противодействия коррупции, на наш взгляд, будет формирование общественного мнения о серьёзной опасности любых коррупционных проявлений, недопущение совершения отдельными лицами, работающими в социальной сфере 


\section{Административное и муниципальное право 7 (103) • 2016}

государственной службы, аморальных коррупциогенных проступков, являющихся началом коррупционного поражения человеческого сознания, повышение правовой культуры населения, чтобы ни со стороны граждан, ни со стороны должностных лиц государственных и частных организаций не возникало даже самого желания вступить в коррупционные отношения. К сожалению, в настоящее время лишь малая часть граждан считает коррупцию абсолютным злом, большинство граждан не против, если возникает острая в этом необходимость, вступить в коррупционные отношения и сохранить их в тайне от правоохранительных органов, большинство должностных лиц в свою очередь не могут устоять от соблазна легкого обогащения в условиях крайне низкой заработной платы, особенно у рядовых служащих. Система мер материального и морального поощрения сотрудников зачастую несправедлива по отношению к честным и добросовестным служащим, вынужденным вступить на коррупционный путь. Необоснованное лишение премий или снижение их размера у трудолюбивых добропорядочных служащих, привлечение их за малейшие провинности к строгим дисциплинарным взысканиям вынужденно и неизбежно ведет их к совершению коррупционных преступлений. В большинстве государственных органах исполнительной власти, особенно в правоохранительной и военной службе, решение о поощрении, премировании или взыскании принимает руководитель данных органов единолично, пусть и на основании служебной проверки, выводы которой также носят субъективный характер и связаны с желанием попросту выжить из рабочего коллектива неугодного им сотрудника. На наш взгляд, такие решения должны приниматься независимой от данного руководителя специальной дисциплинарной комиссией, куда должны входить должностные лица, находящиеся в подчинении у другого руководителя, поскольку только в данном случае выводы по результатам служебных проверок будут носить максимально объективный характер. Неправомерные действия любого руководителя, которому в рамках субординации нельзя возразить, ведут к противоправным деяниям его подчиненных, в том числе к совершению ими коррупционных преступлений. Поэтому ни в коем случае нельзя допускать протекционизма и кумовства со стороны руководителей к подчиненным сотрудникам, и само назначение руководителя должно быть справедливым и заслуженным, большое внимание здесь должно уделяться морально-этической стороне вопроса. Нередко, особенно в органах внутренних дел, мы сталкиваемся с аморальными, грубыми, безграмотными и амбициозными руководителями, выражающихся даже при проведении селекторных совещаний нецензурной бранью, свидетельствующей об отсутствии всякой культуры у такого начальника, с которого, казалось бы, подчиненные должны брать пример. Данные проблемы характерны и для социальной сферы, в особенности медицины и социальной защиты населения, работники которых ведут себя аморально не только по отношению к своим коллегам, но и к самим гражданам, обратившимся к ним за помощью. В результате, у нас самих складывается мнение о том, что помочь здесь может только взятка, тогда и врач, и социальный работник будут с нами гораздо ласковее и сделаю всё, что мы просим, помогут нам в любой, даже самой безнадежной ситуации. И таким образом формируется общественное мнение, о котором говорит А.В. Куракин: «Приведенные цифровые показатели дают возможность сказать, что общественное мнение далеко не однозначно в своем отношении к проблеме коррупции. Достаточное количество граждан рассматривает коррупцию как средство решения своих личных или корпоративных проблем».

Как отметил Президент России, «...в последнее время много дел о коррупции. Я считаю, что это хорошо ...это очищение среды, которая порождает либо защищает коррупцию. Чем более открытая экономика, тем меньше лазеек для коррупции. И в этом направлении мы будем настойчиво действовать. Но самый большой вред от коррупции - морально политический. Потому что устойчивость власти и самого государства зависят от одного важнейшего фактора - доверия людей к органам власти. А если люди видят, что она коррумпирована, то это доверие исчезает. Это самое опасное». Люди, к сожалению, на практике видят, что и медицина, и образование, и социальная защита, и экологическая безопасность глубоко поражены коррупцией и сами, считая коррупцию нормой жизни, предлагают служащим этих органов взятки, даже безо всякого намека на взятку со стороны чиновников, и уж тем более без вымогательства с их стороны. Зачем вымогать и намекать, если и так все прекрасно понимают, что всё решаемо в этой жизни, каждый вопрос, проблема просто имеет свою цену. Если к должностным лицам применимы различные административно-правовые средства предупреждения и пресечения коррупции, то каким образом их можно применить к простым гражданам, провоцирующим должностных лиц вступить с ними в коррупционные отношения, у которых в самом сознании сложилось мировоззрение о том, что в России всё покупается и всё продается. 0 том, что фактически бесплатной медицины нет, а за деньги можно без особых знаний получить диплом в любом частном и даже государственном вузе, за деньги можно стать кем угодно, даже должност- 
ным лицом любого органа власти, руководителем этого органа, дав нужным людям взятку, чтобы потом самому получать эти взятки, злоупотреблять в своих личных корыстных интересах должностным положением, превышать безнаказанно, откупаясь от контролирующих и надзирающих органов, свои полномочия в угоду себе и третьим лицам. Поэтому опасения Президента РФ небезосновательны. Хорошо бы еще, если бы эти важные и красивые слова подкреплялись делами соответствующих органов, чтобы не только В.В. Путин и Д.А. Медведев понимали страшную опасность коррупции, публично объявляя ей войну, но и все должностные лица государственных и муниципальных органов, коммерческих и некоммерческих организаций презирали всей душой любой аморальный коррупциогенный проступок, а всё общество, уплачивая государству налоги, требовало от государственных и муниципальных служащих надлежащего и бесплатного исполнения своих должностных обязанностей, а от самого государства достойную оплату их труда, чтобы самой мысли о коррупции не возникало у таких обладающих властью лиц, чтобы страх перед дисциплинарной ответственностью, перед всеобщим порицанием превышал желание разового неформального обогащения, чтобы граждане, предлагающие взятку, понимали высокую степень риска быть привлеченными к уголовной ответственности, и в то же время знали, что их проблемы чиновник может и должен решать бесплатно, это его прямая обязанность. Ведь не зря же глубокоуважаемый исследователь административно-правовой сущности коррупции А.В. Куракин пишет, что коррупция в системе государственной службы (в особенности, по нашему мнению, в социальной сфере) делает нестабильными общественные отношения, способствует развитию социального напряжения, организованной преступности, а также создает угрозу совершения террористических актов [3]. Террористами-смертниками становятся не только религиозные фанатики, но и вполне обычные люди, от которых отвернулось само государство, погрязшее в коррупции, нарушило их естественные конституционные права (на здоровье, на достойную жизнь и свободное развитие, на защиту от безработицы, на экологическое благополучие, на жилище, на бесплатную медицину, на доступное бесплатное профессиональное образование, социальную защиту и т.д.), сформировав в их сознании чувство ненависти, зависти и озлобленности, как на государственный аппарат, так и на тех невинных граждан, у которых в этой жизни все сложилось хорошо.

Ещё двадцать лет назад Д.Н. Бахрах отмечал, что «...засилье чиновников в решении самых разнообразных дел общества, их эгоизм и корысто- любие, низкий профессиональный уровень стали сегодня бичом для России» [4]. К несчастью, на сегодняшний день практически ничего не изменилось, несмотря на всю проводимую государством антикоррупционную политику.

Л.М. Колодкин справедливо отмечает, что коррупция является социальным явлением, корни которого исходят из недостатков организации государственной службы и особенностей психологии её персонала. Данное обстоятельство вызывает необходимость принятия широкого спектра административно-правовых средств антикоррупционного характера [5].

А.В. Куракин вполне обоснованно, на наш взгляд, указывает, что «административно-правовые средства предупреждения и пресечения коррупции в системе государственной службы РФ должны быть основаны на современных международных и европейских стандартах, действующих в данной сфере. Для того чтобы административно-правовые средства предупреждения и пресечения коррупции в системе государственной службы были ещё более эффективными, целесообразно реализовывать институт административного судопроизводства, а также начать реализовывать механизм реализации права физических и юридических лиц требовать возмещения морального и материального вреда, причиненного коррупционными правонарушениями. Нужно начать реализовывать механизм отмены нормативных правовых актов, принятых в результате актов коррупции, и взыскивать незаконно полученное имущество или стоимость незаконно предоставленных услуг с государственного служащего в результате коррупции».

Вместе с тем все эти средства будут бесполезны, если заработная плата государственного служащего будет нищенской, не позволяющей ему нормально жить и прямо способствующей его вовлечению в коррупционные отношения как личного, так и корпоративного характера. Повышение денежного довольствия работникам, в том числе социальной сферы, конечно, значительно снизит уровень коррупции, но не победит её. Ведь сам же А.В. Куракин указывает, что «низкое денежное содержание государственных служащих также не обеспечивает эффективную служебную деятельность. В настоящее время необходимо существенно увеличить денежное содержание государственных служащих. Это отчасти может способствовать предупреждению и пресечению коррупции в системе государственной службы. Однако лишь одним повышением денежного содержания государственных служащих проблему коррупции не решить. По нашему глубокому убеждению, здесь нужен целый комплекс административно-право- 


\section{Административное и муниципальное право 7 (103) • 2016}

вых, социальных, экономических и информационных мероприятий».

Мы полностью солидарны с позицией А.В. Куракина по данной проблеме. Дополним лишь, для того чтобы данный комплекс мероприятий действовал и приносил ощутимые результаты необходимо их одновременное внедрение во все сферы государственного и коммерческого управления, в особенности в социальную сферу. Нельзя здесь отдавать приоритеты и предпочтения одним мерам перед другими, все они важны и должны применяться на постоянной основе.

Для более детального уяснения ценности административно-правовых мер обеспечения безопасности социальной сферы от коррупции, рассмотрим и проанализируем несколько наиболее распространенных форм проявления коррупции в системе государственной службы РФ. Они имеют место в медицине, образовании, социальной защите, экологической безопасности и иных областях социальной сферы, которая, как отмечалось выше, является одной из наиболее уязвимых для коррупции сфер общественной жизни. Одной из таких форм является протекционизм, которого, на наш взгляд, не должно быть нигде, но исторически сложилось так, что он прочно засел в самой системе организации государственных органов исполнительной власти. Протекционизм можно определить как сложное социально-правовое явление, характеризующееся, в том числе, продвижением по службе и построением карьеры не за счёт своих способностей, а по знакомствам, родственным или дружеским связям должностных лиц с вновь приходящими кандидатами на службу. Наиболее распространенной формой протекционизма является кумовство, землячество, которое формирует в обществе мнение о том, что чужих людей, людей с улицы во властных структурах нет, что посторонним, пусть и способным гражданам на государственную службу по конкурсу, без рекомендаций уважаемых лиц не пробиться. В результате протекционизма на службу приходят низкоквалифицированные люди, которые априори не выполняют должным образом тех задач и функций, которые ставит перед ними государство и общество, тех должностных обязанностей, которые прямо указаны в должностных инструкциях, не бояться быть уволенными с государственной службы, зная, что их покровители этого просто не допустят, и вступают в коррупционные отношения безо всякого страха быть разоблаченными. Протекционизм малоспособных служащих наносит серьезный вред всему государственному механизму, парализует его работу, делает неэффективным выполнение задач и функций, стоящих перед тем или иным государственным органом. Применительно к социальной сфере справедливо замечание К.С. Бельского, который указывает, что «...из числа абитуриентов, попавших в «ректорские списки» и поступивших в вузы, сельское хозяйство получило горе-агрономов, прокуратура - плохих следователей, больница - врачей, не умеющих ставить диагноз. При продвижении подобных специалистов по служебной лестнице общество получает руководителей, у которых при отсутствии кругозора и необходимого интеллектуального уровня акценты в управленческой деятельности смещаются на волевые решения» [6].

Отсюда можно сделать вывод о том, что протекционизм как форма коррупционного проявления существовал всегда, и в советские времена тоже. Опасность протекционизма, на наш взгляд, заключается даже не столько в том, о чем писал уважаемый К.С. Бельский, сколько в том, что он нарушает важнейший конституционный принцип правового государства - равенство всех перед законом, в том числе равный доступ к государственной службе. Конкурсы проходят формально, и победителями их становятся не самые грамотные и квалифицированные специалисты, а знакомые, друзья, свояки должностных лиц данного органа, в особенности тех, кто занимает руководящие должности. Такой сотрудник принимает все корпоративные правила, с ним не будет проблем, он будет исполнять любые указания, даже заведомо зная о том, что они незаконные, он свой человек, часть коррумпированного государственного механизма, он сознает это и согласен работать именно так. Новый человек, прошедший конкурс, «темная лошадка», может не влиться в коллектив, отказаться вступить в коррупционные схемы, более того, заявить о коррупции в правоохранительные органы. Зачем же нужен такой сотрудник, пусть и очень квалифицированный, считают руководители соответствующих органов исполнительной власти, зачем нужны проблемы, которых раньше не было. В результате протекционизм стал вынужденной мерой для коррупционных органов власти, нормой жизни, а конкурсы, вакансии, собеседования всего лишь необходимым в соответствии с законом формализмом. К несчастью, большинство людей относятся к протекционизму как к должному, стараются в жизни завести хорошие знакомства, без которых успешную карьеру построить очень сложно, везде, как говорится, нужны «связи» и покровительства. И чем выше по социальному и должностному статусу покровитель, тем проще и быстрее можно построить карьеру. Чужие люди, пусть и очень грамотные, к сожалению, практически никому сейчас не нужны, поэтому они вынуждены работать не по специальности, постоянно менять работу, а значит стабильности, то, к чему все стремятся, в их жизни нет, государство не дает им возможности 
проявить себя и зачастую толкает на преступный путь. Вот чем особо опасен протекционизм и такие его распространенные в наше время формы как кумовство, землячество, «блат». Социальную сферу, особенно качественную медицину и престижное образование эти формы также не прошли стороной. Частная медицина, базирующая на принципе - как можно больше взять денег с клиента (пациента), высшее образование в престижных вузах «по блату» либо за деньги на бюджетные места, успешная сдача семестровых и государственных экзаменов без знаний за помощь кафедрам либо за взятку, предоставление места в домах престарелых за плату - всё это разрушает государство изнутри, снижает доверие населения к чиновникам, порождает ненависть и презрение к бесполезной власти со стороны народа и, как следствие, провоцирует создание и деятельность экстремистских организаций. Вот почему так важно бороться с коррупцией не только уголовно-правовыми средствами, но и административно-правовыми, поскольку только последними можно противодействовать такому аморальному коррупциогенному проступку как протекционизм, который в среде государственной службы укоренился настолько, что воспринимается всеми нами (большинством из нас) как обычное явление, не представляющее никакой социальной опасности. Ряд руководителей государственных органов исполнительной власти даже видят в протекционизме пользу для государственной машины, ведь свой человек, проверенный всегда лучше чужого, от которого неизвестно, чего можно ожидать. В демократическом правовом государстве, где верховенство закона и равенство всех перед законом закреплено как принцип, такого быть не должно, а любые проявления протекционизма должны как в дисциплинарном, так и в административном порядке наказываться самым строгим образом, поскольку протекционизм зачастую становится началом, как отмечалось выше, преступлений не только коррупционного, но и ещё более опасного для государства и общества характера.

Следует подчеркнуть, что одним из наиболее эффективных способов борьбы с протекционизмом является конкурс на замещение вакантной государственной или муниципальной должности. Однако, как справедливо отмечает А.В. Куракин, «приоритетным способом замещения вакансий на государственной службе продолжает оставаться назначение. Несмотря на необходимость конкурсного замещения должностей государственной службы, назначение на должности государственной службы является приоритетным способом замещения должностей и в настоящее время». Конкурс же, как отмечалось выше, не более чем простая формальность.
Как обоснованно, на наш взгляд, утверждает С.А. Иванов, с кем в свою очередь солидарен и А.В. Куракин, анализ закона о государственной гражданской службе позволяет сделать вывод о том, что в законе имеет место большое количество различного рода исключений. Можно выявить как абсолютные, так и относительные исключения. Первую группу составляют все положения п. 2 ст. 22 закона о государственной гражданской службе, а ч. 3 и 4 можно отнести к относительным исключениям, зависящим от решения представителя нанимателя. Наличие всевозможных исключений привело к мысли, что законодатель снова всех обманул, урезал применение конкурса, превратил «в исключительный способ поступления на государственную службу, который, естественно, будет применяться на практике крайне редко» [7], что и происходит сейчас по вполне объяснимым причинам.

Исследуя административно-правовые средства противодействия коррупции, А.В. Куракин вынужден констатировать тот факт, что по конкурсу замещается лишь незначительная часть государственных должностей государственной службы в силу целого ряда причин как объективного, так и субъективного характера. К числу первых данный учёный относит тот факт, что в Положении о проведении конкурса на замещение вакантной государственной должности государственной гражданской службы установлено, что, кроме наличия вакантной государственной должности, требуется отсутствие резерва для её замещения. Тем самым принцип конкурсного замещения государственных должностей государственной службы и выполнение п. 4 ст. 32 Конституции России, согласно которому граждане России имеют равный доступ к государственной службе, сводится к минимуму. Между тем широкое использование именно данной формы замещения государственных должностей государственной службы способствовало бы предупреждению и пресечению коррупции в системе государственно-служебных отношений.

Вышесказанное в особенности касается социальной сферы, таких её областей, как здравоохранение и образование, наиболее коррупционных, поскольку именно там нужны в первую очередь настоящие профессионалы, а не хорошие знакомые руководства соответствующих учреждений, ведь от уровня их знаний и квалификации зависит здоровье и грамотность подрастающего поколения, будущего нашей страны. Вот где протекционизму не должно быть вообще, где административноправовые меры противодействия ему должны применяться руководителями данных учреждений в максимальной степени, а виновные в протекционизме лица должны быть строго наказаны в дис- 


\section{Административное и муниципальное право 7 (103) 2016}

циплинарном порядке вплоть до увольнения в связи с утратой доверия.

Опираясь на Модельный закон от 3 апреля 1999 г. «О борьбе с коррупцией», который был принят на тринадцатом пленарном заседании Межпарламентской ассамблеи государств - участников СНГ, к правонарушениям, создающим условия для проявления различных форм коррупции, в том числе и в социальной сфере, которые требуют незамедлительного применения административноправовых мер противодействия ей, можно отнести следующие деяния:

- неправомерное вмешательство в деятельность других органов государственной власти, а также коммерческих и некоммерческих организаций;

- использование государственным служащим своих служебных полномочий для решения разнообразных вопросов, связанных с удовлетворением своих личных материальных интересов, а также других лиц;

- $\quad$ предоставление не предусмотренных законом преимуществ (протекционизм, семейственность) при поступлении и продвижении по государственной службе;

- оказание неправомерного предпочтения физическим лицам, индивидуальным предпринимателям, юридическим лицам в предоставлении публичных услуг, а также в оказании содействия в осуществлении предпринимательской деятельности;

- использование в личных или групповых интересах информации, полученной при выполнении служебных обязанностей, если такая информация не подлежит официальному распространению;

- неправомерный отказ в предоставлении информации физическим и юридическим лицам, предоставление которой предусмотрено законом, а также предоставление неполной или недостоверной информации;

- требование от физических и юридических лиц информации, предоставление которой не предусмотрено законом;

- нарушение установленного законом порядка рассмотрения обращений физических и юридических лиц;

- дарение подарков и оказание неслужебных услуг вышестоящим должностным лицам.

Каждый подобный аморальный коррупциогенный проступок должен предупреждаться и пресекаться различными административно-правовыми средствами, среди которых, на наш взгляд, одно из главных мест должно отводиться дисциплинарной ответственности и справедливому объективному дисциплинарному производству. Солидарен в этом с нами и глубокоуважаемый вышеуказанный исследователь административно-правовой сущности коррупции А.В. Куракин, который указывает, что «за проявление данных форм коррупции в системе государственной службы, если они не содержат признаков уголовно-наказуемых деяний, необходимо предусмотреть меры дисциплинарной ответственности в виде понижения в должности, повторное совершение любого из указанных выше правонарушений в течение года со дня наложения дисциплинарного взыскания должно влечь увольнение или иное освобождение от должности». Добавим к сказанному, что привлекать к дисциплинарной ответственности виновных лиц необходимо своевременно и в кратчайшие сроки, взыскание должно быть неотвратимым для всех, в том числе и тех, у кого в верхах большие покровители. Дисциплинарное взыскание должно иметь своей целью воспитание нарушителя и его коллег, оно должно быть соразмерно совершенному проступку и предупредить в дальнейшем совершение им же коррупционных преступлений. Поэтому наряду с недопущением любых форм проявления протекционизма эффективной административно-правовой мерой обеспечения безопасности социальной сферы от коррупции в России является институт дисциплинарной ответственности.

А.В. Куракин в своем исследовании точно, на наш взгляд, подметил, что «меры дисциплинарной ответственности более часто применяются к государственному служащему, нежели меры административной или уголовной ответственности...в законодательстве о государственной службе к середине XIX в. содержались следующие дисциплинарные взыскания: замечание более или менее строгое; выговор более или менее строгий без занесения в послужной список; вычеты из жалованья; выговор более или менее строгий с внесением его в послужной список; перемещение с высшей должности на низшую должность; удаление от должности; вычет из времени службы; отрешение от должности; исключение из службы (ст.65)». В соответствии со статьей 57 Федерального закона от 27 июля 2004 г. «0 государственной гражданской службе Российской Федерации» (далее по тексту Закон о госслужбе) перечень дисциплинарных взысканий гораздо менее обширный и включает в себя: замечание, выговор, предупреждение о неполном должностном соответствии и увольнение.

На наш взгляд, перечень дисциплинарных взысканий должен быть существенно расширен, чтобы руководитель или дисциплинарная комиссия смогли объективно и справедливо оценить степень серьёзности и опасности того или иного дисциплинарного проступка, обстоятельства, отягчающие и смягчающие ответственность, лич- 
ность виновного, условия совершения дисциплинарного проступка. Так, в существующий в статье 57 Закона о госслужбе перечень видов дисциплинарных взысканий следует, по нашему мнению, включить: устное замечание, устный выговор, предупреждение, строгий выговор, понижение в должности, лишение денежных премий на срок до одного года, лишение всех или ряда надбавок к должностному окладу на срок до одного года, перевод на службу в другое подразделение, направление на внеплановую аттестацию, понижение в классном чине на одну ступень. Подобно тому, как уголовное и административное наказание должны иметь целью исправление осужденного и предупреждение совершения им новых правонарушений и преступлений, дисциплинарное взыскание должно иметь те же цели, а также воспитание нарушителя, неукоснительного соблюдения им требований служебной дисциплины и морально-этических правил поведения.

Дисциплинарная ответственность наступает, прежде всего, за нарушение указанных в статье 17 Закона о госслужбе административных запретов, например, запрет замещать должность в гражданской службе в случае избрания на выборную должность в органах местного самоуправления, запрет заниматься предпринимательской деятельностью, запрет разглашать сведения конфиденциального характера или служебную информацию, ставшие ему известными в связи с исполнением должностных обязанностей и т.п.

А.А. Гришковец справедливо отмечает, что «... абсолютное большинство государственных служащих старается не совершать серьёзных правонарушений, имеющих признаки преступлений, допуская при этом в силу различных причин деяния, которые могут быть квалифицированы как должностные проступки» [8]. Это вполне можно применить и к аморальным коррупциогенным проступкам, не содержащих в силу малозначительности признаков составов коррупционных правонарушений и преступлений. Их совершается всегда значительное количество, особенно в таких областях социальной сферы как медицина, образование, социальная защита и экологическая безопасность. Полезность дисциплинарной ответственности особенно значительна для сотрудников, не являющихся в соответствии с приложением 1 к статье 285 УК РФ субъектами коррупционных преступлений, исполняющих свои профессиональные обязанности в сферах образования или медицины. Именно таким административно-правовым средством как привлечение к дисциплинарной ответственности предупреждается и пресекается коррупция в среде врачей и педагогов, не обладающие какими-либо властными полномочиями и не осуществляющими организационно-распорядительные либо административно-хозяйственные функции. О проблемах привлечения к уголовной ответственности данной категории субъектов и путях их решения мы ещё будем детально говорить в следующих главах диссертационного исследования, здесь же укажем на ведущую роль дисциплинарных средств в противодействии коррупции в социальной сфере, в мотивации надлежащего исполнения своих профессиональных обязанностей.

В связи с этим, по мнению знаменитого дореволюционного правоведа Н.М. Коркунова, в отличие от уголовной ответственности дисциплинарная ответственность не предполагает точно фиксированного состава деяния. Тут, как в гражданском праве, всякое нарушение обязанности, вытекающей из установленного законом порядка общественной деятельности, ведет к ответственности, хотя бы данное нарушение порядка и не было предусмотрено законом. В сфере служебной дисциплины это выражается так, что всякое нарушение служебного долга, в каких бы оно ни выражалось формах, предусмотренных или не предусмотренных законом, может влечь за собой дисциплинарное взыскание [9]. Мы полностью согласны с данным мнением, которое в наибольшей степени касается социальной сферы общественной жизни, где аморальные коррупциогенные проступки наиболее распространены и приобретают в настоящее время, к сожалению, характер обычного явления, нормы жизни, а иногда даже правил хорошего тона. К последнему, в частности, относится дарение подарков государственным и муниципальным служащим, врачам, педагогам, социальным работникам за исполнение ими своих прямых обязанностей. На наш взгляд, аморальным коррупциогенным проступком дарение подарков можно признать лишь в случае вымогательства таких подарков со стороны соответствующих субъектов, либо систематическое их дарение одним и тем же лицам. Выражение данным лицам благодарности со стороны граждан за помощь, за профессионализм в решении тех или иных вопросов и проблем не должно быть запрещено ни на юридическом, ни на морально-этическом уровне. Поэтому запретить на законодательном уровне дарение в разумных пределах подарков работникам социальной сферы, по нашему глубокому убеждению, нелепо и даже абсурдно. Дарение и принятие обычных подарков, если это конечно не носит системный характер, не порождает никакой коррупции, а является актом почтения и уважения дарителя к одаряемому и наоборот, пусть даже и за исполнение своих прямых профессиональных или должностных обязанностей. В связи с этим мы категорически не согласны с А.В. Куракиным, при всём уважении к данному 


\section{Административное и муниципальное право 7 (103) • 2016}

ученому, который в своем исследовании утверждает, что перед ратификацией Конвенции Совета Европы «0 гражданско-правовой ответственности за коррупцию» оправданно исключить из статьи 575 Гражданского кодекса Российской Федерации (далее по тексту ГК РФ) предписания, допускающие дарение государственным служащим обычных подарков, стоимость которых не превышает трех тысяч рублей, в связи с их должностным положением или исполнением ими служебных обязанностей.

В то же время вполне обоснованно, как уже отмечалось нами выше, Б.В. Волженкин заявляет, что о подарке не представляется возможным говорить, если этот подарок вымогается должностным лицом под угрозой совершения действия (бездействия), влекущего нарушение законных интересов взяткодателя, или путем умышленной постановки последнего в такие условия, когда он вынужден вручить «подарок» для обеспечения своих правоохраняемых интересов. «Обычный подарок», не влекущий никакой ответственности как для должностного лица, его принявшего, так и для вручившего подарок лица, отличается от взятки не только относительно небольшим размером [10]. Отличается он и отсутствием системного характера дарения, и благородством своих целей, поэтому даром не может являться предоставление дорогих подарков без повода, а также обычных подарков, разрешенных статьей 575 ГК РФ, за совершение незаконных либо аморальных деяний одаряемым в интересах дарителя. Поэтому в УК РФ не оговорен минимальный размер взятки.

Ещё дореволюционный исследователь взяточничества Н.А. Неклюдов полагал, что взятка всегда должна носить характер подкупа и что её необходимо отличать от дара, «...даже в том случае, если бы законодательство признавало необходимым возбранить служащим прием каких бы то ни было проявлений благодарности и признательности, то и тогда нарушение сего формального запрета не могло бы быть рассмотрено как взяточничество, а могло бы составить лишь дисциплинарный проступок, преследуемый или безусловно, или с известными ограничениями» [11].

Анализ юридической литературы позволяет нам сделать вывод о том, что дисциплинарное взыскание как мера дисциплинарной ответственности должно налагаться в процессе осуществления дисциплинарного производства. Такое производство должно быть чётко регламентировано законом о дисциплинарном производстве либо кодексом дисциплинарной ответственности должностных лиц органов государственной власти, необходимость принятия которых уже давно назрела. Солидарен в этом плане с нами и А.В. Куракин. По его мнению, нормативно должны быть определены: момент возбуждения дела о дисциплинарном проступке; задачи дисциплинарного производства; обстоятельства, исключающие производство по делу о дисциплинарном проступке; обстоятельства, смягчающие и отягчающие дисциплинарную ответственность.

Ряд учёных в то же время признают неэффективность дисциплинарной ответственности. В частности, как отмечает С.А. Денисов, «...неэффективность дисциплинарной ответственности связана с её диспозитивностью. Диспозитивность дисциплинарной ответственности позволяет использовать её избирательно для воздействия на принципиальных служащих, не желающих выслуживаться перед начальством. Их «приговаривают» жить по закону, в то время как для служащих, преданных руководителю, создается режим наибольшего благоприятствования и возможность безнаказанно совершать коррупционные проступки»[12] Денисов С.А. Возможности применения института административной ответственности для борьбы с коррупцией государственных служащих // Административная ответственность: вопросы теории и практики. - М., 2005. - С. 200).

Чтобы не допустить подобного режима, необходимо, на наш взгляд, придать дисциплинарной ответственности императивный характер, чтобы дисциплинарные взыскания налагались всем без исключения лицам, совершившим дисциплинарные проступки, в особенности коррупционной направленности. Это следует прямо закрепить в будущем кодексе дисциплинарной ответственности должностных лиц органов государственной власти.

И все-таки основная ценность такого административно-правового средства противодействия коррупции как институт дисциплинарной ответственности проявляется, на наш взгляд, в том, что эффективное и равное ко всем его применение предупреждает совершение должностными лицами коррупционных преступлений, в том числе в социальной сфере.

Наряду с вышеуказанным институтом весьма полезными административно-правовыми мерами обеспечения безопасности социальной сферы от коррупции являются институт поощрения и институт аттестации государственных и муниципальных служащих. Ни для кого не секрет, что материальные и моральные поощрения сотрудников воспитывают в них чувства долга, патриотизма, желание на высоком профессиональном уровне исполнять свои должностные обязанности, не вступая в коррупционные отношения и коррупционные схемы. Аттестация сотрудников позволяет выявить не только их квалификационный уровень, но и морально-этическую составляющую их личности, а также их отношение к коррупции в 
целом и к способам борьбы с ней. Рассмотрим данные административно-правовые средства более подробно.

Весьма эффективным, на наш взгляд, административно-правовым средством противодействия коррупции в социальной сфере является институт поощрения. Справедливое применение его наряду с мерами дисциплинарной ответственности стимулирует работников соответствующих органов и организаций, предупреждает совершение ими коррупционных правонарушений и проступков, способствует укреплению в целом престижа работы и службы в медицинских, образовательных организациях, органах социальной защиты населения и иных отраслях социальной сферы. При этом поощрения должны быть не только морального характера (объявление благодарности, награждение почетной грамотой, ценными подарками и т.п.), но и материального, такие, как постоянное премирование сотрудников не только по итогам работы за квартал, полугодие, год, но и в честь праздников, дней рождений, особого профессионализма и т.п. Поощрения формируют в сознании работников социальной сферы тот факт, что их работу ценят не только обслуживаемое население, но и руководство, администрация учреждений, организаций, где они трудятся на благо общества, что они всегда будут обеспечены за надлежащее исполнение своих должностных и профессиональных обязанностей всем необходимым. И тогда у большинства из них не возникнет желания неформальных обогащений за счёт народа, ведь у значительной части врачей, педагогов, социальных работников складывается мнение, что их работа неблагодарная, заработная плата низкая, а подношения и взятки от населения обычное и полезное явление, поскольку государство либо руководство частных учреждений им недоплачивает заработную плату, не поощряет за высокие показатели работы, за положительные отзывы пенсионеров, пациентов, студентов и иных лиц. Как следствие, они вынужденно вступают в коррупционные отношения, работодатель сам провоцирует их совершать коррупционные преступления, выплачивая мизерную заработную плату, полностью не соответствующую сложности их работы, уровню их опыта, образования и квалификации, задерживая заработную плату иногда по несколько месяцев, материально или даже морально не поощряя их. Поэтому, анализируя зарубежный опыт борьбы с коррупцией, А.В. Куракин пишет, что «одним из действенных административно-правовых средств предупреждения и пресечения коррупции в системе государственной службы ведущих зарубежных государств является материальное обеспечение государственных служащих. Высокая заработная плата позволяет со- хранять на службе профессиональные и честные кадры». Несомненно, это можно применить даже в большей степени к нашей стране, где рядовые государственные служащие с размерами своих окладов находятся за чертой бедности, но уходить со службы не спешат, поскольку она позволяет им безнаказанно вступать в коррупционные правоотношения, злоупотреблять властью и положением, авторитетом государственной и муниципальной службы, своей профессиональной честью.

По нашему глубокому убеждению, именно высокое материальное обеспечение работников, постоянные их поощрения являются самыми эффективным административно-правовыми средствами противодействия коррупции, в том числе и в наиболее подверженной ей социальной сфере. Низкое денежное довольствие большинства государственных и муниципальных служащих, работников коммерческих и некоммерческих организаций социальной сферы деятельности, отсутствие денежных поощрений является, на наш взгляд, главной причиной совершения ими коррупциогенных проступков, а в дальнейшем и коррупционных преступлений. Не очень-то боятся сотрудники дисциплинарной и даже уголовной ответственности, когда трудятся целыми днями, стараются изо всех сил, а дома в холодильнике постоянно либо чего-то не хватает, либо он практически пустой. Финансовые проблемы в семьях таких сотрудников, особенно высококвалифицированных, создают постоянные конфликты и вынуждают вступать в коррупционные отношения даже самых честных, справедливых и неподкупных граждан, разочаровывают их в жизни, порождают ненависть и зависть к более успешным и менее образованным людям, обществу и государству, а значит и к законам, существующим в нашей стране, включая уголовный закон. И это при том, что сами власть имущие должностные лица, руководители лично себя никогда не обделяют материально, выписывают себе баснословные премии, отчитываются перед обществом о проведенных мероприятиях по борьбе с коррупцией, хотя сами создают все условия для её процветания и развития, а зачастую даже активно участвуют в коррупционных схемах.

Ещё Томас Гоббс, размышляя над обязанностями государства, писал, что «...цель награждений достигнута, если люди, хорошо и с минимальными затратами общественных средств послужившие государству, так хорошо награждаются, что этим создается для других стимул честно и верно служить государству и приобретать те знания, которые сделали бы их способными служить еще лучше» [13]. Здесь мы полностью солидарны с великим философом и считаем, что данное высказывание особенно актуально в наши дни и в нашем государстве. 


\section{Административное и муниципальное право 7 (103) • 2016}

А.В. Куракин, наиболее глубокий исследователь административно-правовой сущности коррупции в Российской Федерации, отдает должное в своей работе институту поощрения как эффективному административно-правовому средству противодействия коррупции в системе государственной службы РФ. В частности, он обоснованно, на наш взгляд, отмечает, что «институт поощрений и награждений государственного служащего должен учитывать такие принципы, которые позволяли бы поощрять отличившихся и достойных государственных служащих, а также применять меры дисциплинарного воздействия к тем руководителям, которые поощряют служащего не за деловые или профессиональные качества, а исходя из собственной корыстной заинтересованности. Престиж государственной службы вообще и государственной гражданской службы в частности может быть отчасти восстановлен с увеличением денежного содержания государственных служащих. Однако лишь одним повышением денежного содержания государственных служащих проблему коррупции не решить. По нашему глубокому убеждению, здесь нужен целый комплекс административно-правовых, социальных, экономических и информационных мероприятий». Но даже весь подобный комплекс мероприятий не решит полностью проблему коррупции, поскольку даже при самых благоприятных условиях работы и службы, найдутся работники, которые будут брать взятки, злоупотреблять должностным положением, превышать полномочия и совершать иные коррупционные деяния ради личной выгоды или выгоды третьих лиц. Есть люди, для которых моральные принципы, авторитет государственной и муниципальной службы, клятва Гиппократа, присяга, честь всего лишь пустая формальность, а деньги, особенно большие деньги это смысл всей жизни, цель карьеры. С такими лицами административно-правовыми и конституционно-правовыми средствами противодействия коррупции бороться бесполезно, здесь эффективны только уголовноправовые меры борьбы с ней, которым, собственно говоря, и посвящено наше диссертационное исследование. Но даже максимально эффективные уголовно-правовые средства не остановят коррупцию, а в лучшем случае лишь снизят её уровень, поскольку пока живы люди, способные к подкупу и подкупаемые, победить коррупцию невозможно, по крайней мере, в нашей стране точно. А хуже всего то, что большинство российских граждан не считают коррупцию преступлением, а воспринимают её как жизненную необходимость, лёгкий способ решения любых, даже самых сложных проблем, поскольку, по их зачастую вполне обоснованному мнению, всё имеет свою цену.
Но это не означает, что бороться с коррупцией бесполезно. Снижение уровня коррупции позволяет государству, обществу, каждому человеку развиваться и процветать, реализовывать свой профессиональный потенциал на благо своей страны. Поэтому противодействие коррупции, в том числе и в социальной сфере, должно быть одной из главных задач и функций государства при любых формах правления и политических режимах. И конечно весьма важную роль здесь должны играть сами граждане, у которых с малых лет необходимо в сознании формировать нетерпимость к коррупции и осуждение любых форм коррупционных проявлений.

Не менее важной и действенной административно-правовой мерой обеспечения безопасности социальной сферы от коррупции является институт аттестации. В статье 48 Закона о госслужбе закреплено положение о том, что аттестация гражданского служащего (к которым относятся большинство работников социальной сферы) проводится в целях определения его соответствия замещаемой должности гражданской службы.

Мы полностью поддерживаем мнение А.В. Куракина о том, что аттестация государственных служащих как форма корпоративного контроля должна занимать важное место в механизме административно-правового регулирования государственной службы, а также является важным административно-правовым средством предупреждения и пресечения коррупции в системе государственной службы РФ. Вместе с тем, эффективность данного средства резко снижается с проникновением в процедуры аттестации элементов протекционизма, когда на результат аттестации в немалой степени влияют знакомства, родственные связи аттестуемых лиц, а не их знания и личные профессиональные качества. В тоже время, как показала аттестация в органах внутренних дел, для многих руководителей аттестация служит законным средством избавления от неугодных сотрудников, которые по причине зависти, личной неприязни, стремления к справедливости и иным неслужебным причинам попали в немилость к начальнику. Руководители увольняют таких лиц, а на их места приходят «свои» люди и успешно проходят по протекции этих же руководителей все ступени аттестации. В результате общество избавляют от грамотных, принципиальных профессионалов и заменяют их посредством аттестации низкоквалифицированными кадрами или вообще дилетантами, что недопустимо и должно всячески пресекаться государством как административно-правовыми, так и уголовно-правовыми мерами. Виновные в такой псевдоаттестации руководители должны не просто увольняться с занимаемых должностей, а неотвратимо привлекаться к уголовной ответ- 
ственности за злоупотребление должностными полномочиями. Солидарен в этом с нами и А.В. Куракин, который отмечает, что аттестацию в системе государственной службы нужно рассматривать максимально широко и использовать её возможности не для сведения личных счетов с аттестуемым служащим, а для предупреждения и пресечения коррупции, а также укрепления законности и дисциплины в системе государственной службы РФ.

Исходя из вышесказанного, следует согласиться с Ю.Н. Стариловым, который отметил, что аттестация государственных гражданских служащих в более широком понимании, чем это закреплено в законе, решает следующие задачи: обеспечение законности в системе государственной службы; создание профессионального корпуса государственных служащих; установление служебного соответствия государственного служащего занимаемой должности или выполняемой работе; выявление перспектив применения потенциальных способностей и возможностей государственного служащего; определение необходимости повышения квалификации, профессиональной подготовки или переподготовки государственного служащего; применение к государственному служащему мер юридической ответственности и поощрения за успехи в выполнении служебных обязанностей; предупреждение и пресечение правонарушений и коррупции в системе государственной службы [14].

Основное в аттестации как средстве предупреждения и пресечения коррупции - это комплексная оценка служащего на основании реальных показателей его служебной деятельности [15].

В юридической литературе, посвященной проблеме аттестации государственных служащих, справедливо отмечается, что важным в механизме аттестации является процедура её проведения, индивидуальный подход, объективность, внимательное отношение не только к тому, что скажут члены аттестационной комиссии, но и то, что доложит сам аттестуемый сотрудник по вопросам, которые возникают в ходе аттестации [16].

Только беспристрастная, максимально объективная аттестация является, по нашему глубокому убеждению, эффективным средством противодействия коррупции, формальная аттестация с заведомо готовым решением только способствует коррупции, порождает ее, укрепляет её дестабилизирующий потенциал.

Еще в 1998 г. Ю.А. Розенбаум отмечал, что серьёзных преобразований в системе оценки персонала аппарата государственных органов пока не произошло. Поэтому не получает должного развития аттестация государственных служащих и мало что слышно об объявлении конкурсов на замещение государственных должностей, хотя о многих ва- кансиях известно. Все это сказывается на качестве государственного аппарата, непомерно раздутого и малокомпетентного [17]. К сожалению, в настоящее время, несмотря на проводимую в стране антикоррупционную политику, мало что изменилось.

Вышеперечисленные и некоторые другие обстоятельства не позволяют внедрить современные оценочные технологии в процедуру аттестации, как административно-правового средства противодействия коррупции, в том числе и в социальной сфере, а также осуществить на практике дифференцированный подход при оценке личностных и профессиональных качеств государственного служащего с целью предупреждения и пресечения коррупциогенного поведения с его стороны.

Таким образом, подводя итог настоящей главе, следует подчеркнуть, что среди правовых мер обеспечения безопасности социальной сферы от коррупции наиболее важное значение имеют конституционно-правовые и административно-правовые меры противодействия ей. В свою очередь, административно-правовые меры базируются на конституционно-правовых мерах и средствах противодействия коррупции, закрепленных в самой Конституции РФ, Основном законе нашей страны, в соответствии с которым был, пусть и с запозданием, принят Закон о коррупции, а государство в лице правоохранительных и контролирующих органов объявило данному негативному социально-опасному явлению непримиримую войну. Значение административно-правовых мер и средств обеспечения безопасности социальной сферы от коррупции для детального определения и глубокого понимания, исследования уголовно-правовых и криминологических мер противодействия коррупционным преступлениям в социальной сфере очень велико и проявляется, прежде всего, в том, что без должного практического применения указанных и исследованных нами административно-правовых средств противодействия коррупции в целом невозможно достичь положительного результата в борьбе с коррупционной преступностью. Причины, условия, обстоятельства формирующие личность коррупционера и корруптера, находятся в административно-правовом аспекте коррупции, поэтому противодействовать коррупции, на наш взгляд, необходимо вначале именно административно-правовыми средствами, чтобы не допустить совершения коррупционных преступлений, предупредить или даже пресечь подготовку к таким преступлениям, и только в случае, если преступление всё равно совершается, то применять уже криминологические меры и уголовно-правовые средства противодействия ей, о которых речь пойдет уже в следующих главах нашего диссертационного исследования. 


\section{Библиография:}

1. Куракин А.В. Государственная служба и коррупция. - М., 2009. - С. 157.

2. Подкупающая откровенность: социологи выяснили, что думают российские граждане о причинах коррупции и способах борьбы с ней // Российская газета. - 2008. - 6 июня. С. 5.

3. Куракин А.В. Административно-правовые аспекты пресечения коррупции в сфере исполнительной власти // Право и политика. - 2001. - № 12. - С. 35.

4. Бахрах Д.Н. Государственная служба: основные понятия, ее составляющие, содержание, принципы // Государство и право. - 1996. - № 12. - С. 10.

5. Колодкин Л.М. Административно-правовые проблемы предупреждения коррупции в государственном управлении // Предупреждение организованной и коррупционной преступности средствами различных отраслей права. - М., 2002. - С. 188.

6. Бельский К.С. Персональная ответственность в советском государственном управлении (моральные, экономические, политические аспекты). - М., 1989. - С. 10.

7. Иванов С.А. Правовое регулирование отношений в сфере государственной службы // ЭЖ Юрист. - 2004.- № 6. C. 23.

8. Гришковец А.А. Правовое регулирование государственной гражданской службы в РФ. - М., 2003. - С. 139.

9. Коркунов Н.М. Русское государственное право. Т. 1. - СПб., 1892. - С. 724.

10. Волженкин Б.В. «Обычный подарок» или взятка? // Законность. - 1997. - № 4. - С. 25.

11. Неклюдов Н.А. Взяточничество и лихоимство // Юридическая летопись. - 1890. - Июнь. - С. 516.

12. Денисов С.А. Возможности применения института административной ответственности для борьбы с коррупцией государственных служащих // Административная ответственность: вопросы теории и практики. - М., 2005. С. 200.

13. Гоббс Т. Левиафан, или материя, форма и власть государства церковного и гражданского. Соч. - M., 1991. - Т. II. C. 272.

14. Старилов Ю.Н. Государственная служба: теоретико-правовое исследование. - Воронеж, 1996. - С. 302.

15. Горбачев А.И. Теория и организация государственной службы: Альбом схем. - М., 2001. - С. 35.

16. Базилевский И.А. Реформа государственной гражданской службы РФ // Бюллетень Министерства юстиции РФ. 1999. - № 1. - С. 73.

17. Розенбаум Ю.А. Проблемы оценки государственного служащего // Государство и право. - 1998.- № 8. - С. 24.

18. Костенников М.В., Куракин А.В. Административно-правовое противодействие коррупции в системе государственной службы и в деятельности сотрудников полиции Российской Федерации и зарубежных государств. // Полицейская деятельность. - 2011. - 1. - С. 10 - 16.

19. Куракин А.В., Кулешов Г.Н. Государственная служба и информационные технологии // NB: Административное право и практика администрирования. - 2013. - 12. - С. 1 - 20. DOI: 10.7256/2306-9945.2013.12.10701. URL: http:// www.e-notabene.ru/al/article_10701.html

20. Куракин А.В., Костенников М.В. Административно-правовое противодействие коррупции в системе государственной службы и в деятельности сотрудников полиции Российской Федерации и зарубежных государств // Полицейская и следственная деятельность. - 2013. - 1. - С. 65 - 83. DOI: 10.7256/2409-7810.2013.1.735. URL: http://www.e-notabene.ru/pm/article_735.html

\section{References (transliterated):}

1. Kurakin A.V. Gosudarstvennaya sluzhba i korruptsiya. - M., 2009. - S. 157.

2. Podkupayushchaya otkrovennost': sotsiologi vyyasnili, chto dumayut rossiiskie grazhdane o prichinakh korruptsii i sposobakh bor'by s nei // Rossiiskaya gazeta. - 2008. - 6 iyunya. S. 5.

3. Kurakin A.V. Administrativno-pravovye aspekty presecheniya korruptsii v sfere ispolnitel'noi vlasti // Pravo i politika. 2001. - № 12. - S. 35 .

4. Bakhrakh D.N. Gosudarstvennaya sluzhba: osnovnye ponyatiya, ee sostavlyayushchie, soderzhanie, printsipy // Gosudarstvo i pravo. - 1996. - № 12. - S. 10.

5. Kolodkin L.M. Administrativno-pravovye problemy preduprezhdeniya korruptsii v gosudarstvennom upravlenii // Preduprezhdenie organizovannoi i korruptsionnoi prestupnosti sredstvami razlichnykh otraslei prava. - M., 2002. S. 188.

6. Bel'skii K.S. Personal'naya otvetstvennost' v sovetskom gosudarstvennom upravlenii (moral'nye, ekonomicheskie, politicheskie aspekty). - M., 1989. - S. 10.

7. Ivanov S.A. Pravovoe regulirovanie otnoshenii v sfere gosudarstvennoi sluzhby // EZh Yurist. - 2004.- № 6. - S. 23.

8. Grishkovets A.A. Pravovoe regulirovanie gosudarstvennoi grazhdanskoi sluzhby v RF. - M., 2003. - S. 139.

9. Korkunov N.M. Russkoe gosudarstvennoe pravo. T. 1. - SPb., 1892. - S. 724.

10. Volzhenkin B.V. «Obychnyi podarok» ili vzyatka? // Zakonnost'. - 1997. - № 4. - S. 25.

11. Neklyudov N.A. Vzyatochnichestvo i likhoimstvo // Yuridicheskaya letopis'. - 1890. - Iyun'. - S. 516.

12. Denisov S.A. Vozmozhnosti primeneniya instituta administrativnoi otvetstvennosti dlya bor'by s korruptsiei gosudarstvennykh sluzhashchikh // Administrativnaya otvetstvennost': voprosy teorii i praktiki. - M., 2005. - S. 200.

13. Gobbs T. Leviafan, ili materiya, forma i vlast' gosudarstva tserkovnogo i grazhdanskogo. Soch. - M., 1991. - T. II. - S. 272.

14. Starilov Yu.N. Gosudarstvennaya sluzhba: teoretiko-pravovoe issledovanie. - Voronezh, 1996. - S. 302. 


\section{Государственная и муниципальная служба и проблемы противодействия коррупции}

15. Gorbachev A.I. Teoriya i organizatsiya gosudarstvennoi sluzhby: Al'bom skhem. - M., 2001. - S. 35.

16. Bazilevskii I.A. Reforma gosudarstvennoi grazhdanskoi sluzhby RF // Byulleten' Ministerstva yustitsii RF. - 1999. № 1. - S. 73.

17. Rozenbaum Yu.A. Problemy otsenki gosudarstvennogo sluzhashchego // Gosudarstvo i pravo. - 1998.- № 8. - S. 24.

18. Kostennikov M.V., Kurakin A.V. Administrativno-pravovoe protivodeistvie korruptsii v sisteme gosudarstvennoi sluzhby i v deyatel'nosti sotrudnikov politsii Rossiiskoi Federatsii i zarubezhnykh gosudarstv. // Politseiskaya deyatel'nost'. 2011. - 1. - C. $10-16$.

19. Kurakin A.V., Kuleshov G.N. Gosudarstvennaya sluzhba i informatsionnye tekhnologii // NB: Administrativnoe pravo i praktika administrirovaniya. - 2013. - 12. - C. 1 - 20. DOI: 10.7256/2306-9945.2013.12.10701. URL: http://www.enotabene.ru/al/article_10701.html

20. Kurakin A.V., Kostennikov M.V. Administrativno-pravovoe protivodeistvie korruptsii v sisteme gosudarstvennoi sluzhby i v deyatel'nosti sotrudnikov politsii Rossiiskoi Federatsii i zarubezhnykh gosudarstv // Politseiskaya i sledstvennaya deyatel'nost'. - 2013. - 1. - C. 65 - 83. DOI: 10.7256/2409-7810.2013.1.735. URL: http://www.e-notabene.ru/pm/ article_735.html 